Notes

\title{
The Use of an Enzyme-based Sensor Array to Fingerprint Proteomic Signatures of Sera from Different Mammalian Species
}

\author{
Shunsuke Tomita, ${ }^{* \dagger}$ Saki Yokoyama, ${ }^{* *}$ Ryoji Kurita,* Osamu Niwa,* and Keitaro Yoshimoto**† \\ *Biomedical Research Institute, National Institute of Advanced Industrial Science and Technology, \\ 1-1-1 Higashi, Tsukuba, Ibaraki 305-8566, Japan \\ **Department of Life Sciences, Graduate School of Arts and Sciences, The University of Tokyo, 3-8-1 Komaba, \\ Meguro, Tokyo 153-8902, Japan
}

\begin{abstract}
A cross-reactive sensor array consisting of polyion complexes (PICs) between anionic enzymes and poly(ethylene glycol)modified (PEGylated) polyamines has been used to identify the source of mammalian sera. Although the catalytic activity of enzymes was inhibited by PIC formation with PEGylated polyamines, the subsequent addition of sera caused enzyme releases from PICs through competitive interactions between PICs and serum proteins, generating unique response patterns of changes in the enzyme activity. Linear discriminant analysis of the obtained patterns enabled the discrimination of five sera from different mammalian sources.
\end{abstract}

Keywords Biosensors, discriminant analysis, enzymes, block-copolymers, serum

(Received July 14, 2015; Accepted August 20, 2015; Published February 10, 2016)

\section{Introduction}

The protein concentration levels in biofluids, such as serum and urine, provide essential information concerning drug mechanism and diagnosis. This is because proteins are the final form of the gene product, and therefore are directly associated with biological functions. At present, the most extensively used protein detection method relies on the antigen-antibody reaction. However, in addition to well-known issues in antibody-based technologies, such as high cost and time consumption, the development of efficient antigen-antibody pairs is challenging, since many proposed marker proteins are possibly nonspecific to particular biological events. ${ }^{1}$

An alternative approach to protein recognition has emerged in the past decade, ${ }^{2}$ in which proteins are identified using "optical cross-reactive sensor arrays" that are inspired by the gustatory and olfactory system. Rather than aiming at attaining the potency and selectivity of antibodies, this approach utilizes an array of nonspecifically, but differentially, responsive receptors to generate unique optical fingerprints that can be statistically analyzed to discriminate individual analyte proteins. There have been many attempts into array-based protein sensing. ${ }^{3}$ Typical examples include the use of conjugates between fluorescent molecules and quenchers, ${ }^{4-7}$ where interactions between the conjugates and analyte proteins produce response patterns of changes in the fluorescent intensities. We have recently developed enzyme-based sensor arrays consisting of polyion complexes (PICs) between anionic enzymes and poly(ethylene glycol)-modified (PEGylated) polyamines for the discrimination of human plasma proteins ${ }^{8}$ and structurally similar homologous

† To whom correspondence should be addressed.

E-mail: s.tomita@aist.go.jp; ckeitaro@mail.ecc.u-tokyo.ac.jp albumins. ${ }^{9}$

The successful discrimination of pure protein analytes by optical cross-reactive sensor arrays has led to further attempts to analyze complex biofluids, which would be a powerful approach in disease diagnosis and proteomics. The earlier efforts involved the identification of proteins spiked in human serum ${ }^{7,10,11}$ or urine. ${ }^{12,13}$ However, little has so far been demonstrated concerning the analysis of differences between real biofluids, while the discrimination of human sera from normal and hepatoma patients has very recently been achieved by a sensor array consisting of fluorescent gold nanoclusters. ${ }^{14}$ To test the applicability of our PIC sensor array, in this study, five sera from different mammalian species were selected as model analytes, which commonly contain up to 10000 proteins with an extraordinary dynamic range of concentration, spanning more than 10 orders of magnitude. ${ }^{15,16}$ We found that a cross-reactive PIC sensor array can be used for identifying the source of mammalian sera with $100 \%$ accuracy. Our sensing system can recognize proteomic signatures of complex sera, in addition to pure proteins ${ }^{8,9}$ and cell culture media containing secreted proteins from human cells, ${ }^{17}$ suggesting the versatility of an enzyme-based sensor array to profile real biofluids.

\section{Experimental}

Reagents and chemicals

$\beta$-Galactosidase from Aspergillus oryzae (GAO), lipase from Aspergillus niger (LAN), 4-methylumbelliferyl- $\beta$-D-galactopyranoside (MUG), 4-methylumbelliferyl oleate (MUO), Triton $\mathrm{X}-100$, and 3-( $N$-morpholino)propanesulfonic acid (MOPS) were obtained from Sigma Chemical Co. Dimethyl sulfoxide (DMSO) was obtained from Wako Pure Chemical Industries. Horse serum, rabbit serum, and bovine serum were obtained 
Source of PIC library

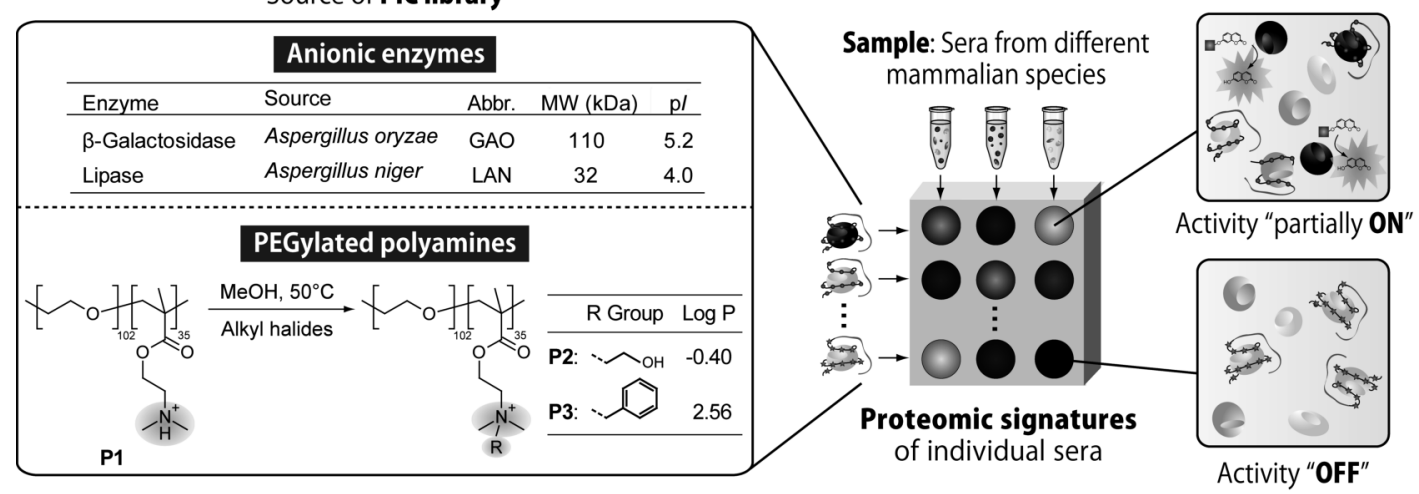

Fig. 1 Schematic illustration of a PIC sensor array to fingerprint proteomic signatures of mammalian sera. Cross-reactive PICs consisting of two anionic enzymes and three PEGylated polyamines were mixed with sera, causing changes in the enzyme activity due to competitive interactions between PICs and serum proteins. $\log P$ values of $\mathrm{R}$ groups in PEGylated polyamines were calculated by the program ALOPGs. ${ }^{27}$

from Cosmo Bio Co., Ltd. Human serum and fetal bovine serum were obtained from Thermo Scientific. Poly(ethylene glycol)-block-poly(N,N-dimethylaminoethyl methacrylate) (PEG$b$-PAMA, P1) and quaterinized PEG- $b$-PAMAs (PEG- $b$ QPAMAs) (P2 and P3) were synthesized as reported previously. ${ }^{9}$ The degrees of polymerization of P1 - P3 were 102 for PEG and 35 for PAMA or QPAMA.

\section{Enzyme assays}

Various concentrations of PEGylated polyamines were mixed with $15.6 \mathrm{nM}$ GAO or $20.8 \mathrm{nM}$ LAN in $10 \mathrm{mM}$ MOPS (pH 7.0) in 96-well plates (96 Well Black Flat-Bottom Polystyrene NBS $^{\mathrm{TM}}$ Microplates; Corning Inc.). After incubation for $30 \mathrm{~min}$, $8 \mu \mathrm{L}$ of substrate in DMSO was added to $192 \mu \mathrm{L}$ of enzyme solutions. Time course of the increase in fluorescence at $460 \mathrm{~nm}$ was then recorded using a microplate reader (Fluoroskan Ascent; Thermo Labsystems) with excitation at $355 \mathrm{~nm}$. The final concentrations were $15.0 \mathrm{nM}$ GAO and $1.0 \mathrm{mM}$ MUG; $20.0 \mathrm{nM}$ LAN, $0.05 \mathrm{mM}$ MUO, and 0.3\% Triton X-100.

\section{Sensing of mammalian sera}

The total protein in the sera was quantified using the Bradford Reagent (Sigma Chemical Co.) according to the manufacturer's instructions, and then diluted to a total protein concentration of $200 \mu \mathrm{g} / \mathrm{mL}$ with $10 \mathrm{mM}$ MOPS (pH 7.0). Aliquots of $172 \mu \mathrm{L}$ of solutions containing PEGylated polyamines and enzymes were loaded into each well of the 96-well plates, followed by the addition of $20 \mu \mathrm{L}$ of diluted serum. The solutions were incubated for $30 \mathrm{~min}$ at $30^{\circ} \mathrm{C}$ to reach equilibrium. After $8 \mu \mathrm{L}$ of the substrate in DMSO was mixed with the solutions, the time course of the fluorescence increase was recorded using the microplate reader with excitation at $355 \mathrm{~nm}$. The final concentrations were $15.0 \mathrm{nM}$ GAO, PEGylated polyamines (120 nM P1, $100 \mathrm{nM} \mathbf{P 2}$ or $80 \mathrm{nM} \mathrm{P3})$ and $1.0 \mathrm{mM}$ MUG; $20 \mathrm{nM}$ LAN, PEGylated polyamines ( $80 \mathrm{nM} \mathrm{P1}$ and P2 or $40 \mathrm{nM}$ P3), $0.05 \mathrm{mM}$ MUO and $0.3 \%$ Triton X-100. This process was repeated with 6 PICs in six replicates each. This data set matrix was subjected to linear discriminant analysis (LDA) using SYSTAT 13 (Systat Inc.).

\section{Results and Discussion}

The present sensor design involves a library of polyion complexes (PICs) between anionic enzymes and complementary charged poly(ethylene glycol)-modified polyamines (Fig. 1). ${ }^{8,9,17}$ The catalytic activity of enzymes was reversibly inhibited without denaturing by non-covalent PIC formation with PEGylated polyamines. ${ }^{18}$ Since each PIC was expected to possess different affinities for serum proteins, the addition of mammalian sera to PICs would render unique patterns of changes in enzyme activity through competitive interactions between PICs and serum proteins. Generated patterns possibly reflect proteomic signatures of individual sera, and are therefore available for discrimination using a chemometric method.

To confirm the assumption, we employed a total of six PICs consisting of two anionic enzymes and three PEGylated polyamines (Fig. 1). Lipase from Aspergillus niger (LAN) possesses peculiar binding affinity toward hydrophobic surfaces, ${ }^{19}$ which may provide a higher binding affinity toward hydrophobic proteins in sera as compared with hydrophilic $\beta$-galactosidase from Aspergillus oryzae (GAO). A PEGylated polyamine (PEG- $b$-PAMA, P1) and quaterinzed PEG- $b$-PAMAs with hydrophilic (P2) and hydrophobic (P3) functional groups were synthesized as reported previously. ${ }^{9}$ The number of positive charges of the QPAMA segment at $\mathrm{pH} 7.0$ was nearly two-fold higher than the PAMA segment, since $\mathrm{p} K_{\mathrm{a}}$ of the PAMA segment is around 7.0. ${ }^{9}$ Both the number of positive charges and the functionality of polyamines would affect the interactions between PEGylated polyamines/enzymes/serum proteins.

An activity assay of enzyme-catalyzed hydrolysis at various concentrations of PEGylated polyamines in $10 \mathrm{mM}$ MOPS buffer ( $\mathrm{pH}$ 7.0) was investigated to determine the optimized concentration ratio between PEGylated polyamines and enzymes. From the kinetics of the fluorescent intensity derived from enzymatically produced 4-methylumbelliferone (Fig. 2A), the normalized rate of substrate hydrolysis was calculated and plotted versus the ratio of PEGylated polyamines to enzymes (Fig. 2B). The catalytic activity of both GAO and LAN toward their corresponding fluorogenic substrates decreased in the order P3 $>$ P2 $>$ P1, suggesting that the greater was the number of cations and the higher hydrophobicity in polyamines, 
A
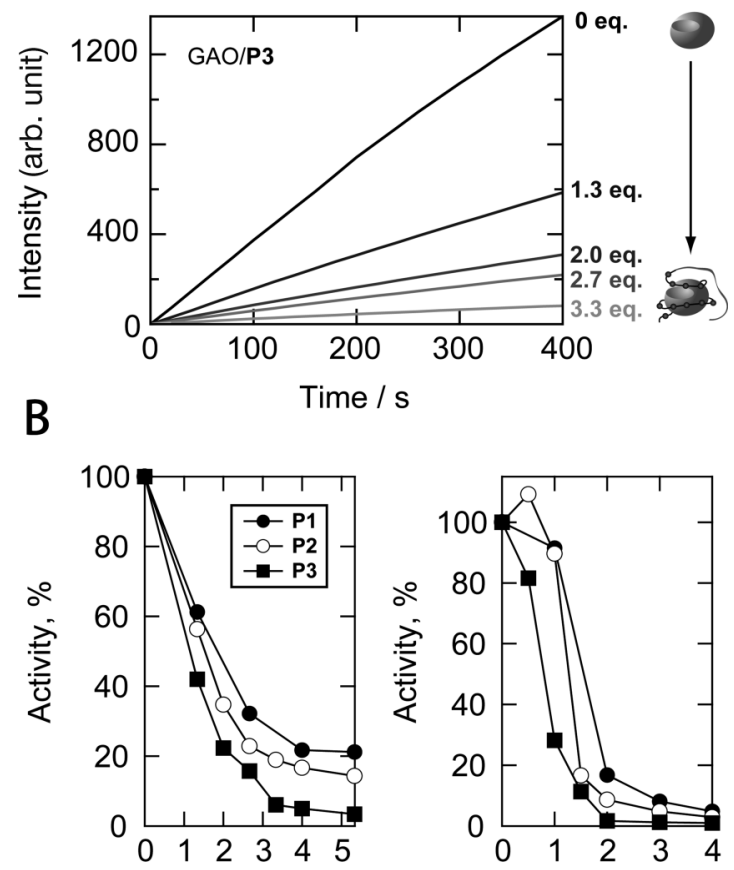

[Polymer]/[GAO]
[Polymer]/[LAN]

Fig. 2 (A) Time courses of the increase in the fluorescence intensity upon the addition of $\mathbf{P 3}$ to GAO. (B) Normalized enzyme activities in the presence of various concentrations of PEGylated polyamines. PEGylated polyamines were titrated to $15 \mathrm{nM}$ GAO and $20 \mathrm{nM} \mathrm{LAN}$ in $10 \mathrm{mM}$ MOPS (pH 7.0).

the greater was the inhibitory effect on the enzyme activity. These different affinities of PEGylated polyamines were expected to provide a variety of cross-reactivity to a PIC library.

The sensor array was then constructed by mixing the optimized concentrations of enzymes and PEGylated polyamines in a 96-well microplate, followed by the addition of diluted serum with a constant amount of proteins $(20 \mu \mathrm{g} / \mathrm{mL})$. After $30 \mathrm{~min}$ of incubation, substrate solutions were finally added in order to determine the changes in the enzyme activity. Five sera from different mammalian sources (horse, rabbit, bovine, fetal bovine, and human) were chosen to test our sensor array. The resulting data matrix (6 PICs $\times 5$ sera $\times 6$ replicates) was analyzed through linear discriminant analysis (LDA), which is a wellestablished chemometric method for multigroup classification..$^{20}$ Stepwise analysis with different PIC set(s) (i.e., Jackknife classification procedure) was first used to determine a minimal PIC set for sufficient discrimination. Interestingly, the combination of only two PICs (GAO/P2 and LAN/P1) provided $100 \%$ accuracy (Table 1), indicating that the use of different enzymes and polyamines provided effective cross-reactivity to PIC sensor arrays for the discrimination of five different sera.

Figure 3A shows the changes in the enzyme activity for PICs of GAO/P2 and LAN/P1 upon the addition of mammalian sera. These data were converted to discriminant scores that were used to provide a graphical representation of how LDA is clustering in patterns (Fig. 3B). All clusters were successfully separated from each other. It is well known that serum is composed of five major fractions, identified by serum protein electrophoresis: albumin, $\alpha_{1}, \alpha_{2}, \beta$, and $\gamma$-globulins. As also indicated from Table 2, sera from individual mammalian species show unique electrophoretic protein patterns. ${ }^{21}$ In addition, the primary

Table 1 Classification accuracy for serum discrimination

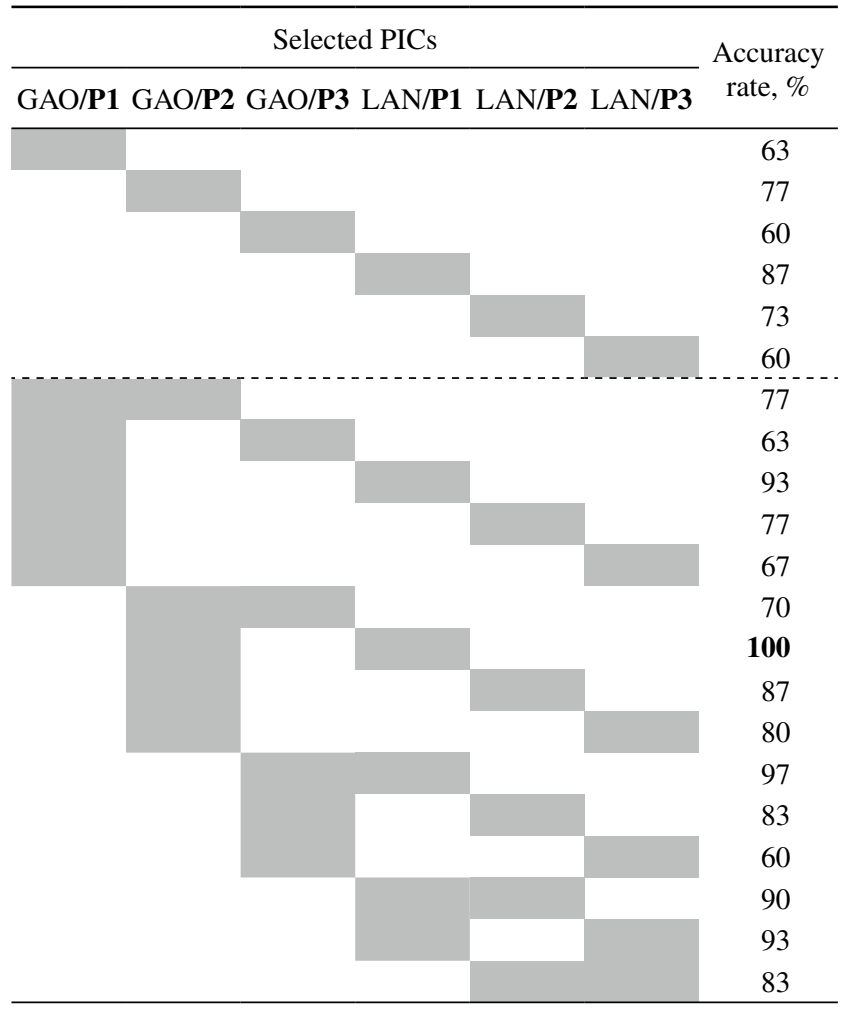

A

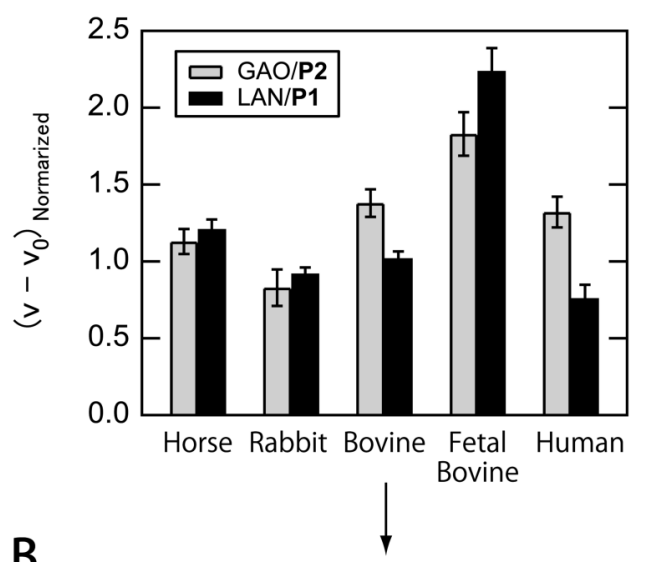

B

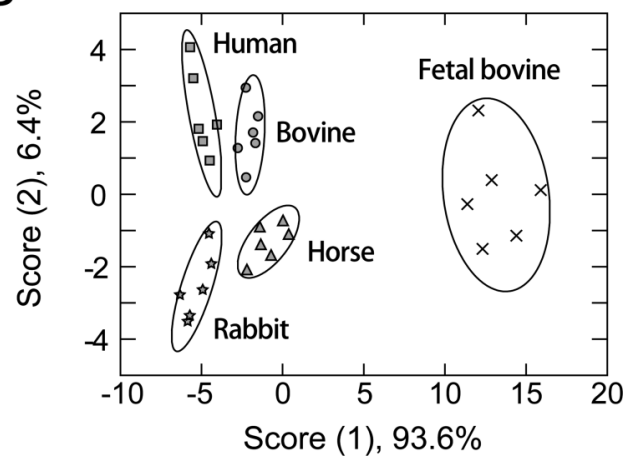

Fig. 3 Sensing of mammalian sera using two PICs (GAO/P2 and LAN/P1). (A) Enzyme activity patterns for five mammalian sera. Each value represents the average of six parallel measurements with $1 \mathrm{SD}$. The values were divided by the root mean square of corresponding PIC data to facilitate a visual comparison between each of the PIC results. (B) Discriminant score plot. The ellipses represent confidence intervals $( \pm 1 \mathrm{SD})$ for the individual sera. 
Table 2 Total protein concentration and protein fractions for mammalian sera

\begin{tabular}{|c|c|c|c|c|c|c|}
\hline & $\begin{array}{c}\text { Total } \\
\text { protein/ } \\
\mathrm{g} \mathrm{L}^{-1}\end{array}$ & $\begin{array}{c}\text { Albumin, } \\
\%\end{array}$ & $\begin{array}{c}\alpha_{1^{-}} \\
\text {Globulin, } \\
\%\end{array}$ & $\begin{array}{c}\alpha_{2^{-}} \\
\text {Globulin, } \\
\%\end{array}$ & $\begin{array}{c}\beta- \\
\text { Globulin, } \\
\%\end{array}$ & $\begin{array}{c}\gamma- \\
\% \\
\text { Globulin, }\end{array}$ \\
\hline Horse $^{23}$ & 61.5 & 55.9 & 4.2 & 11.3 & 14.4 & 14.2 \\
\hline Rabbit $^{24}$ & 66.1 & 59.1 & 2.3 & 7.3 & 14.5 & 16.6 \\
\hline Bovine $^{25}$ & 63.8 & 63.3 & 4.9 & 7.5 & 12.7 & 11.6 \\
\hline $\begin{array}{l}\text { Fetal } \\
\text { bovine }^{a}\end{array}$ & 33.0 & 54.2 & 3.7 & 24.6 & 14.2 & 3.3 \\
\hline Human $^{26}$ & 72.9 & 53.3 & 8.0 & 10.4 & 13.8 & 14.2 \\
\hline
\end{tabular}

a. Values were taken from the supplier.

sequences of homologous proteins are different between mammalian species. For example, the sequence identity between serum albumin from horse, bovine, rabbit and human is around $70 \% .^{22}$ These differences in composition and structure of serum proteins presumably allowed to generate differential patterns of sera. Note that fetal bovine serum was clearly separated from other sera (Fig. 3B). This is likely due to a significantly small fraction of $\gamma$-globulin and a large fraction of $\alpha_{2}$-globulin in fetal bovine serum (Table 2). The sensitivity of the PIC sensor array is dependent on the type of enzyme/ substrate pair and the monitoring time for the enzymatic reaction, because the signal of competitive interactions between PICs and analyte proteins are amplified through enzymatic hydrolysis of substrates. We have successfully discriminated sera containing $20 \mu \mathrm{g} / \mathrm{mL}$ proteins, and previously 4.4 to $38.7 \mu \mathrm{g} / \mathrm{mL}$ proteins ${ }^{8,9}$ and $0.25 \mu \mathrm{g} / \mathrm{mL}$ secreted proteins from cultured cells, ${ }^{17}$ whereas our PIC sensor array would identify more dilute biofluids-based analytes by selecting suited enzyme/ substrate pairs and experimental conditions for target analytes.

\section{Conclusions}

To our knowledge, this is the first report concerning a crossreactive sensor array that can discriminate sera from different mammalian species. The combined use of natural enzymes and synthetic PEGylated polyamines to construct PIC libraries led to a successful discrimination of five sera by using only two PICs. We believe that our enzyme-based sensor array will be applied for the array-based sensing of various real biofluids.

\section{Acknowledgements}

This work was supported by a Grant-in-Aid for JSPS Young Scientists (B, 26810074), and Scientific Research (B, 24350037).

\section{References}

1. E. P. Diamandis, J. Natl. Cancer Inst., 2010, 102, 1462.
2. A. T. Wright and E. V. Anslyn, Chem. Soc. Rev., 2006, 35, 14.

3. D. Margulies and A. D. Hamilton, Curr. Opin. Chem. Biol., 2010, 14, 705 .

4. C. C. You, O. R. Miranda, B. Gider, P. S. Ghosh, I. B. Kim, B. Erdogan, S. A. Krovi, U. H. Bunz, and V. M. Rotello, Nat. Nanotechnol., 2007, 2, 318.

5. D. F. Moyano, S. Rana, U. H. Bunz, and V. M. Rotello, Faraday Discuss., 2011, 152, 33.

6. S. S. Chou, M. De, J. Luo, V. M. Rotello, J. Huang, and V. P. Dravid, J. Am. Chem. Soc., 2012, 134, 16725.

7. H. Pei, J. Li, M. Lv, J. Wang, J. Gao, J. Lu, Y. Li, Q. Huang, J. Hu, and C. Fan, J. Am. Chem. Soc., 2012, 134, 13843.

8. S. Tomita and K. Yoshimoto, Chem. Commun., 2013, 49, 10430.

9. S. Tomita, T. Soejima, K. Shiraki, and K. Yoshimoto, Analyst, 2014, 139, 6100.

10. M. De, S. Rana, H. Akpinar, O. R. Miranda, R. R. Arvizo, U. H. Bunz, and V. M. Rotello, Nat. Chem., 2009, 1, 461.

11. Y. Tao, X. Ran, J. Ren, and X. Qu, Small, 2014, 10, 1667.

12. O. R. Miranda, H. T. Chen, C. C. You, D. E. Mortenson, X. C. Yang, U. H. Bunz, and V. M. Rotello, J. Am. Chem. Soc., 2010, 132, 5285.

13. X. Yang, J. Li, H. Pei, D. Li, Y. Zhao, J. Gao, J. Lu, J. Shi, C. Fan, and Q. Huang, Small, 2013, 9, 2844.

14. S. Xu, X. Lu, C. Yao, F. Huang, H. Jiang, W. Hua, N. Na, H. Liu, and J. Ouyang, Anal. Chem., 2014, 86, 11634.

15. N. L. Anderson and N. G. Anderson, Mol. Cell. Proteomics, 2002, 1,845 .

16. J. N. Adkins, S. M. Varnum, K. J. Auberry, R. J. Moore, N. H. Angell, R. D. Smith, D. L. Springer, and J. G. Pounds, Mol. Cell. Proteomics, 2002, 1, 947.

17. S. Tomita, M. Sakao, R. Kurita, O. Niwa, and K. Yoshimoto, Chem. Sci., 2015, 6, 5831.

18. T. Kurinomaru, S. Tomita, S. Kudo, S. Ganguli, Y. Nagasaki, and K. Shiraki, Langmuir, 2012, 28, 4334.

19. G. Fernandez-Lorente, C. Ortiz, R. L. Segura, R. FernandezLafuente, J. M. Guisan, and J. M. Palomo, Biotechnol. Bioeng., 2005, 92, 773.

20. P. Jr Anzenbacher, P. Lubal, P. Bucek, M. A. Palacios, and M. E. Kozelkova, Chem. Soc. Rev., 2010, 39, 3954.

21. D. H. Moore, J. Biol. Chem., 1945, 161, 21.

22. M. Chruszcz, K. Mikolajczak, N. Mank, K. A. Majorek, P. J. Porebski, and W. Minor, Biochim. Biophys. Acta, 2013, 1830, 5375.

23. B. Riond, B. Wenger-Riggenbach, R. Hofmann-Lehmann, and H. Lutz, Vet. Clin. Pathol., 2009, 38, 73.

24. V. Rupic, S. Muzic, N. Stipic, J. Skrlin, and L. BacarHuskic, Acta Vet. Brno, 1999, 68, 91.

25. L. G. Longsworth, R. M. Curtis, and R. H. Pembroke, J. Clin. Invest., 1945, 24, 46.

26. F. B. Seibert, M. V. Seibert, A. J. Atno, and H. W. Campbell, J. Clin. Invest., 1947, 26, 90.

27. I. V. Tetko, J. Gasteiger, R. Todeschini, A. Mauri, D. Livingstone, P. Ertl, V. A. Palyulin, E. V. Radchenko, N. S. Zefirov, A. S. Makarenko, V. Y. Tanchuk, and V. V. Prokopenko, J. Comput. Aid. Mol. Des., 2005, 19, 453. 